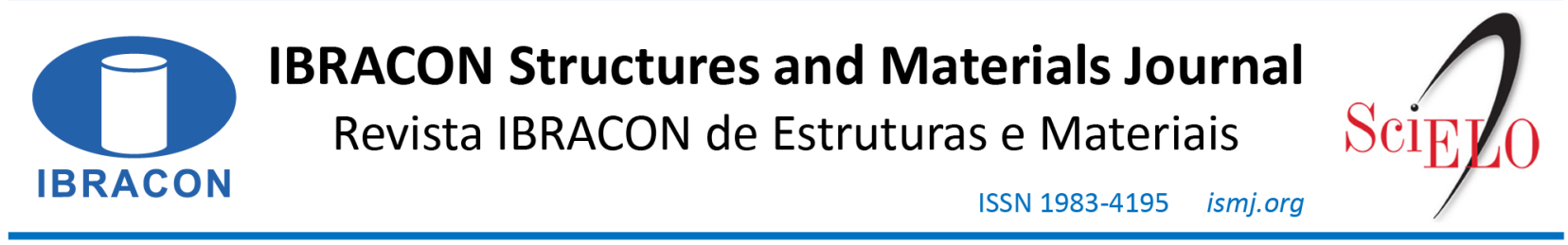

ORIGINAL ARTICLE

\title{
Numerical evaluation of the slab effective width in steel- concrete composite box girder bridges
}

\section{Determinação via simulação numérica da largura efetiva de lajes de pontes mistas de aço e concreto em seção caixão}

\author{
Renato Silva Nicoletti ${ }^{\mathrm{a}}$ \\ Alex Sander Clemente de Souza ${ }^{\mathrm{a}}$ (D) \\ ${ }^{a}$ Universidade Federal de São Carlos - UFSCar, Departamento de Engenharia Civil - DECiv, São Carlos, SP, Brasil
}

Received 21 January 2019

Accepted 26 May 2020

\begin{abstract}
Bridges are structures built to overcome obstacles and allow continuity of transport routes. In the search for efficient construction systems, steel-concrete composite structures, especially box girder bridges, emerged. The American AASHTO and European EN 1994-2-2 standards present design procedures for this type of bridge, but there are still doubts about which portion of the concrete slab contributes to each web strength in composite section (effective width). The present paper aims to evaluate, by numerical analysis in the Abaqus ${ }^{\circledR}$ software, the concrete slab effective width and to verify whether the expressions for its calculation in composite I-girder bridges are valid for box girder sections. After analyzing the results, it was found that the standards recommendations for composite I-girder cannot be applied directly to box girders. Finally, based on the numerical analysis, an equation was proposed to calculate the effective width of steelconcrete composite box girder bridges.
\end{abstract}

Keywords: effective width, steel-concrete composite bridges, box section, numerical analysis.

\begin{abstract}
Resumo: Pontes são estruturas construídas para vencer obstáculos e permitir a continuidade de vias de transporte. Na busca por sistemas construtivos eficientes, vieram à tona as estruturas mistas de aço e concreto, em especial as pontes em seção caixão. As normas americanas AASHTO e europeias EN 1994-2-2 procedimentos de projeto para essa tipologia de pontes, porém ainda há dúvidas sobre qual parcela do tabuleiro contribui para a resistência de cada alma da seção mista (largura efetiva). O presente trabalho busca avaliar numericamente no software Abaqus ${ }^{\circledR}$, a largura efetiva da laje de concreto e verificar se as expressões existentes perfis tipo "I" são válidas para perfis do tipo caixão. Após a análise dos resultados, constatou-se que as recomendações normativas para vigas mistas com seções tipo "I" não podem ser aplicadas diretamente para seções do tipo caixão. Por fim, com base nos resultados, propôs-se uma equação para o cálculo da largura efetiva de pontes mistas de aço e concreto em seção caixão.
\end{abstract}

Palavras-chave: largura efetiva de laje, pontes mistas de aço e concreto, seção caixão, análise numérica.

How to cite: R. S. Nicoletti and A. S. C. Souza. "Numerical evaluation of the slab effective width in steel-concrete composite box girder bridges," Rev. IBRACON Estrut. Mater., vol. 14, no. 1, e14110, 2021, https://doi.org/10.1590/S1983-41952021000100010

\section{INTRODUCTION}

The association between steel and concrete has been an efficient solution for the formation of steel-concrete composite structural elements, such as beams, slabs and columns. Several authors have dedicated themselves to the study of steel-concrete composite elements and defended their advantages and applications. Of these, it is worth mentioning Veríssimo [1], De Nardin and Souza [2], Kotinda [3] and Souza et al. [4].

The use of composite structures can bring important advantages in relation to reinforced concrete structures and steel structures, such as dispensing formwork and shoring; reduction of own weight and volume of the structure; reduction of foundation costs; increased dimensional accuracy of construction, reduced consumption of structural steel 
and less need for protection against fire and corrosion in steel profiles. In Brazil, the most common applications are for building construction. However, steel-concrete composite structures can be applied with advantages in the construction of bridges, enabling the construction of large spans, adding speed and rationalization in construction and also reducing costs and environmental impacts.

A steel-concrete composite system is called one in which a steel profile (laminated, welded or cold formed) resists together with concrete, forming a composite element - beam, column, slab or even a connection. The interaction between the concrete and the steel profile can take place through mechanical means (connectors, dents, projections, etc.), by friction or, in some cases, by simple adhesion and load sharing. With regard to steel-concrete composite bridges, the most common structural systems are in I-girders and in box girders (simple or double).

In particular, the composite box section consists of a closed section in which the sides (webs) and the lower part (bottom flange) are made of steel, constituting a closed section through the connection of the top box flange with the concrete slab, using shear connectors. In other words, the box section is formed with the union of a steel box girder interconnected with the concrete slab. Rectangular or trapezoidal sections are the most common. The bridge can have its cross section with only one box or multiple boxes depending on the width, span and loads. As advantages of the box section, mention is made of the greater torsional rigidity, facilities in terms of construction and maintenance, durability and aesthetic factors. Some alternatives for the design of steel-concrete composite box girder bridges are presented in Figure 1 together with a detail of the steel-concrete interface, highlighting the position of the shear connectors.

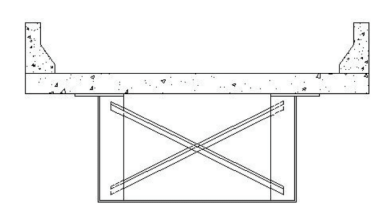

$\underline{\text { Simple rectangular box }}$

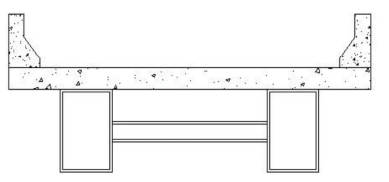

Double connected rectangular box

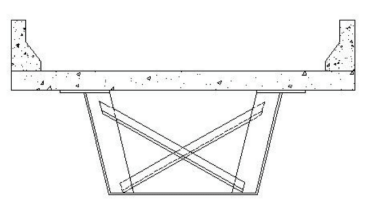

Simple trapezoidal box

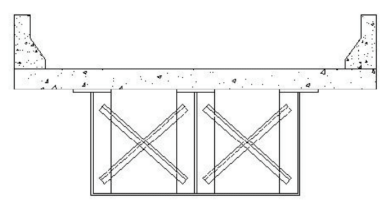

Simple multicellular rectangular box

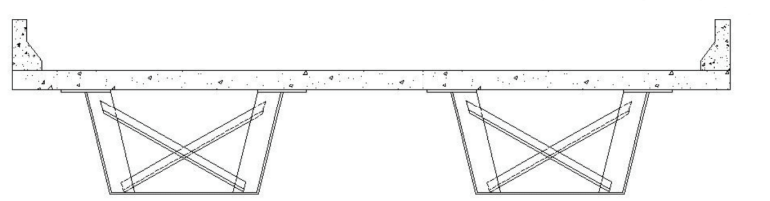

Double trapezoidal box

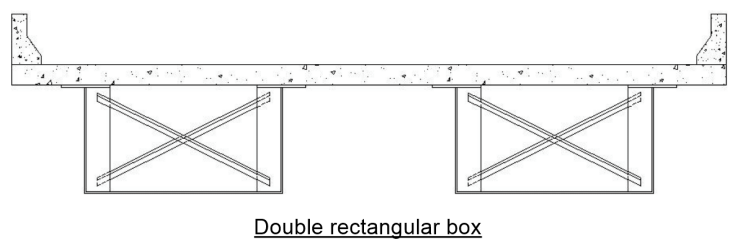

Double rectangular box

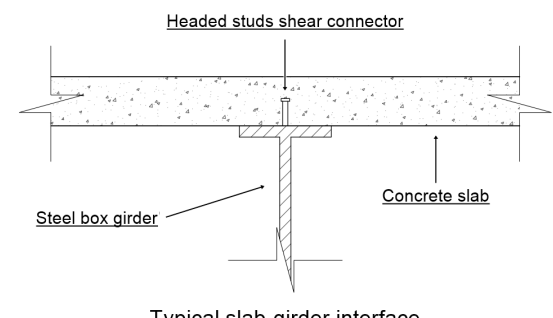

Typical slab-girder interface

Figure 1. Examples of steel-concrete composite box girder bridges. Adapted from Pinho and Bellei [5]. 
In the construction of buildings, the use of steel-concrete composite elements is already established and consolidated in Brazil, with national technical standards that establish the parameters of design and construction. However, for the construction of bridges, the potential of composite structures is still little explored due to several factors, such as, for example, the lack of specific technical standards, design tools and limited technical knowledge.

The availability of national bibliography for steel-concrete composite bridges is limited and is out of date. It is worth mentioning the work of Pinho and Bellei [5], which presents an overview of typologies and design criteria for steel and steel-concrete composite bridges based on foreign standards.

Orlando et al. [6] and Souza [7] present studies on the behavior, analysis and design of steel-concrete composite bridges, however the emphasis is bridges focuses on I-girders. Faria and Pravia [8] synthetically present the design procedures of the American standard for steel-concrete composite box girder bridges.

In foreign countries, technical and scientific paper about steel-concrete composite box girder bridges are more abundant and can be classified into: development of new construction and design technologies [9], [10]; development of codes, manuals, practical examples of design and analysis and design procedures [11], [12].

With regard to design codes, in Brazil there is no specific standard for the design of steel-concrete composite box girder bridges. The American standards AASHTO [13] and European EN 1994-2-2 [14] present design procedures for this type of bridge, however there are still doubts and uncertainties about which portion of the board that really contributes to the resistant capacity of the composite section, that is, about the effective width of the concrete slab.

The need to improve Brazil's road infrastructure is very important for the country's economic development. In addition to political and economic issues, difficulties in meeting this demand are also affected by technical factors. In this context, it is urgent to develop constructive systems for bridges and road and rail viaducts that are capable of meeting the need for infrastructure quickly, economically and with the least possible environmental impact.

Undoubtedly the steel-concrete composite box bridges are among the most promising construction technologies, requiring more investment in scientific and technological research, design tools and transfer of knowledge to the technical environment to make this construction system viable.

In this context, one of the problems that must be faced in the design of steel-concrete composite box girder bridges is the definition of the effective width of the concrete slab that contributes to the joint steel-concrete behavior in the web region. There are no specific recommendations in the Brazilian standard ABNT NBR 8800: 2008 [15], which deals with steel and steel-concrete composite structures in buildings, nor in the American standards AASHTO [13] and European EN 1994-2-2 [5]. For this reason, the effective width of the steel-concrete composite box girder section is determined with the recommendations for composite I-girders. In this context, the present paper aims to determine, through numerical analyzes, the effective slab width in steel-concrete box girder bridges.

\section{Objectives}

Determine, by numerical analyzes, the effective width of the slab that contributes to the cross section of the web in steel-concrete composite box girder bridges.

The specific objectives are to:

- Analyze the validity and adapt, if necessary, the expressions presented by AASHTO [13], EN 1994-2-2 [14] and ABNT NBR 8800: 2008 [15] for steel-concrete composite girders with I-profiles to be applied to box girders;

- Study the influence of the slab height, the length of the longitudinal span, the distance between box (in double box girder configuration) and the distance between webs (in simple box girder configuration) on the effective slab width of steel-concrete composite box girder bridges.

\section{Effective width}

In steel-concrete composite beams, the stresses in the slab are not uniform, so that they present maximum stresses close to the beams, producing a non-flat section after loading. Such a phenomenon is called the shear lag effect.

To exemplify, it is assumed a simply supported composite beam with a concentrated load applied in the middle of the span see Figure 2a. In this situation, the shear diagram on the slab is linear and, as a result, the displacements due to deformations in the longitudinal direction are parabolic in the transversal direction. On the left side of the beam, the shear is positive. The right side of the beam, in turn, is subjected to negative shear. Figure $2 \mathrm{~b}$ shows the displacement distribution in both cases. For geometric compatibility to be maintained in the middle of the span, changes in the distribution of bending stresses as well as in the shear distribution are necessary. These stress changes result in the shear lag effect. 


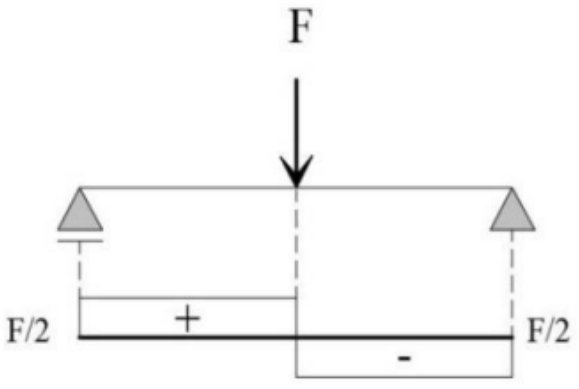

(a)

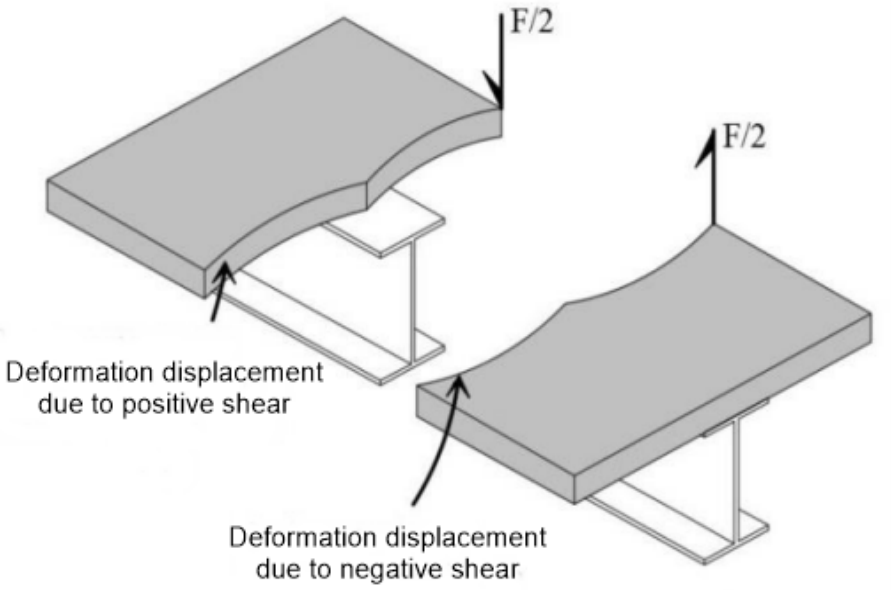

(b)

Figure 2. Displacements due to incompatible deformations. Adapted from Reginato [16].

To consider this effect, there is the effective width concept, reducing the width of the slab and allowing the hypotheses of flat section to be maintained, within acceptable limits for design routines. In other words, only a portion of the slab is considered effective in contributing to the resistant capacity of the composite elements and, therefore, it becomes unnecessary to consider the non-uniform stress distribution. Figure 3 summarizes the concept of effective width.

In Figure 3, the effective width $\left(b_{e f}\right)$ is determined when the stress distribution area ABCDEFG is equal to an abcd area, delimiting the width in which stresses are maximum and uniform. It is also observed that the maximum normal stress occurs at the point of connection of the steel beam with the concrete slab, due to the greater existing rigidity of this region, and decreases as it moves away from the center of the beam.

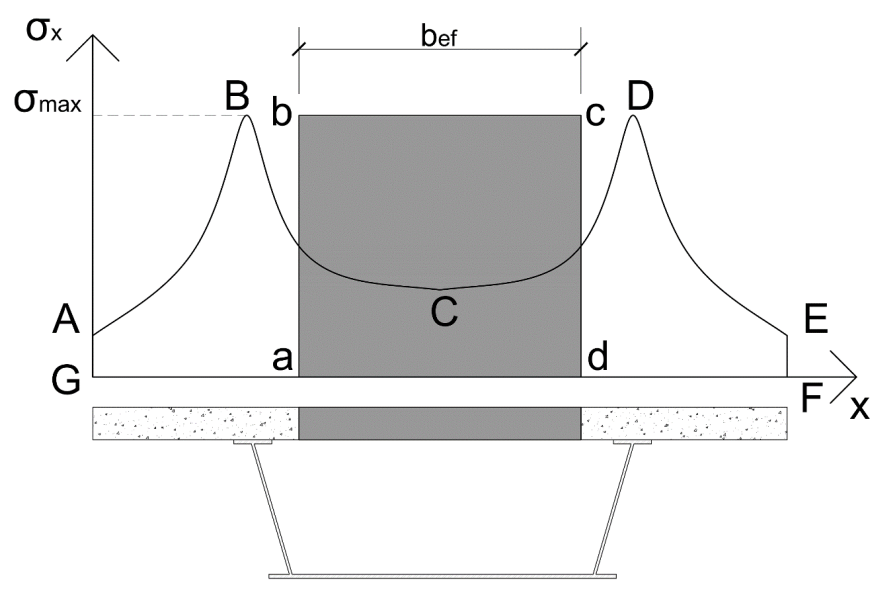

Figure 3. Effective width concept.

The effective width phenomenon has been investigated by several researchers in the literature, and it is worth highlighting the work of Patel [17], Amadio and Fragiacomo [18], Salama and Nassif [19], Abbu, Ekmekyapar and Ozakça [20], Zhu et al. [21] and Yuan et al. [22].

In general, two main approaches are found in the literature for the assessment of effective width. The first is related to the state of stress on the slab. In this situation, the effective width is conceptualized as the width of the slab that supports efforts equal to that of the real slab, assuming that the normal stresses are constant in the effective width of 
the slab and equivalent to the maximum stress $\left(\sigma_{x \max }\right)$ on the center line of the beam steel. Equation 1 summarizes this concept mathematically.

$b_{e f}=\frac{1}{\sigma_{x \max }} \int_{-\frac{b}{2}}^{+\frac{b}{2}} \sigma_{x} d y$

Where $b_{e f}$ denotes the effective width, $\sigma_{x}$ the normal longitudinal stresses, $\sigma_{x m a x}$ the maximum normal stress, and $b$ the geometric width of the concrete slab of the composite section.

In turn, a second approach is specialized in the stiffness of the steel-concrete section. In this case, the deflection of the composite beam must be calculated and, subsequently, by means of analytical expressions, obtain the derivation of the second moment corresponding to the area that would result in the same deformation value of the idealized beam. Finally, based on the second equivalent moment of area, the effective width is estimated. In the present work, the first method was used.

For steel-concrete composite beams with I-profiles, mainly for building beams, an effective slab width is already in use in standards. Table 1 presents the requirements of Brazilian and European standards for calculating the effective width of steel-concrete composite simply supported beams with I-profiles.

Table 1. Recommendations for calculating the effective width in simply supported beams in buildings.

\begin{tabular}{|c|c|}
\hline ABNT NBR $8800[15]$ & EN 1994-2-2 [14] \\
\hline The effective width must be less than or equal to: & $\begin{array}{l}\text { When the slab extends to both sides of the beam, the effective } \\
\text { width must be less than or equal to: }\end{array}$ \\
\hline$\cdot \frac{1}{8}$ of the span of the composite beam; & $\cdot \frac{1}{4}$ of the span of the composite beam; \\
\hline $\begin{array}{l}\text { - Half the distance between the center of the analyzed beam and } \\
\text { the adjacent beam; }\end{array}$ & - Average distance between axes of adjacent beams. \\
\hline \multirow[t]{3}{*}{$\begin{array}{l}\text { - Distance from the center line of the beam to the edge of a } \\
\text { cantilevered slab. }\end{array}$} & $\begin{array}{l}\text { In turn, when the slab extends to only one side, the effective } \\
\text { width is limited to: }\end{array}$ \\
\hline & $\cdot \frac{1}{8}$ of the span of the composite beam; \\
\hline & $\begin{array}{l}\text { - Half the distance between the center of the analyzed beam } \\
\text { and the adjacent beam. }\end{array}$ \\
\hline
\end{tabular}

For steel-concrete composite bridges with I-girders, the American standard AASHTO [13] defines what the effective calculation width of the area must not exceed:

- One-fourth of the span length of the girder;

- The distance center to center of girders;

- Twelve times the least thickness of the slab.

However, for box girders, there is no specific standardization and the validity of the expression recommended for I-girders is not known.

\section{METHODOLOGY}

In analyses, 35 numerical models were developed, 19 with single box configuration and 16 with double box configuration, in the Abaqus ${ }^{\circledR}$ software [23], varying geometric parameters such as the slab height, span length, the distance between box (double box configuration) and the distance between webs (simple box configuration) - the main parameters that determine the effective width in normalizations.

The geometric design of the elements was performed according to the recommendations of AASHTO [13]. On all models, set the cross-section width to $12.80 \mathrm{~m}$. As for the steel box girder: for the models in the simple box configuration, a height of $3.50 \mathrm{~m}$ and a thickness of the profiles of $41.28 \mathrm{~mm}$ were adopted; and for the models in the 
double box configuration, a height of $2.00 \mathrm{~m}$ and a thickness of $41.28 \mathrm{~mm}$ were adopted. Trapezoidal box girders were used.

In all models, normal stresses were collected in the middle of the span and at the loading step at the beginning of the slab's plastic behavior. With such data, a non-uniform distribution curve was drawn up and the effective width was calculated using the quotient of the area below the curve by the maximum normal stress. Finally, the results found numerically were compared with the effective analytical width prescribed by the normalizations for steel-concrete composite I-girder bridges.

\section{Numerical analysis and model conception}

To discretize the steel and concrete components of the girder and slab, respectively, the solid element C3D8R was used, which has 8 nodes with 3 degrees of freedom per node (translations in the $\mathrm{x}, \mathrm{y}$ and $\mathrm{z}$ directions), as this element supports the analysis plastic with high deformations and displacements.

The steel girder could be discretized by means of shell elements, requiring less processing time. However, the use of shell elements is more usual when the thickness of the component can be disregarded. Thus, given that the best finite element to discretize concrete is the hexahedral element and this element provides more accurate results also for the steel profile, the choice of finite element C3D8R is justified.

The modeling of the shear connectors was not performed and total interaction between the two materials was admitted through the "Tie constraint" tool of the Abaqus ${ }^{\circledR}$ software [23], which couples the nodes of the steel-concrete interface, making both materials resist together to efforts, totally preventing relative slipping between the two contact surfaces. Figure 4 shows a scheme of the surfaces where the Tie constraint was applied.

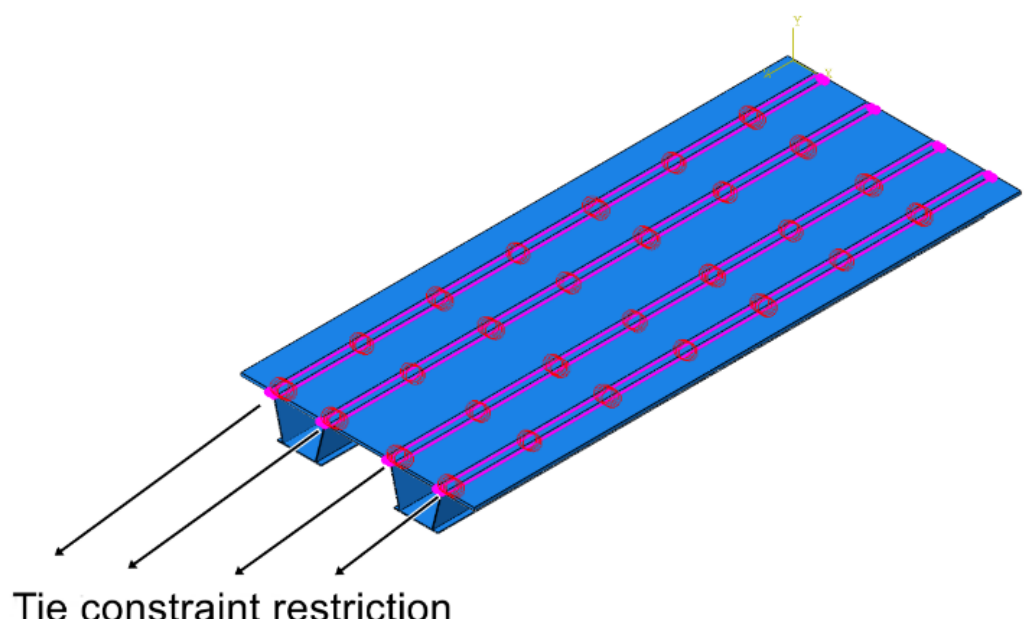

Tie constraint restriction

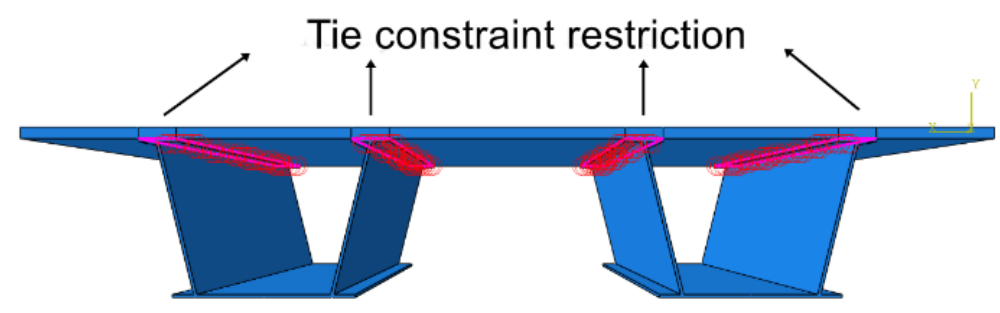

Figure 4. Relative interface displacement restricted by the Abaqus ${ }^{\circledR}[23]$ "tie constraint" tool.

For all models simply supported restrictions was adopted. Thus, the movement in the $\mathrm{y}$ and $\mathrm{z}$ directions was restricted along the lower table on both steel box girder supports. Figure 5 shows such boundary conditions imposed on Abaqus ${ }^{\circledR}[23]$. 


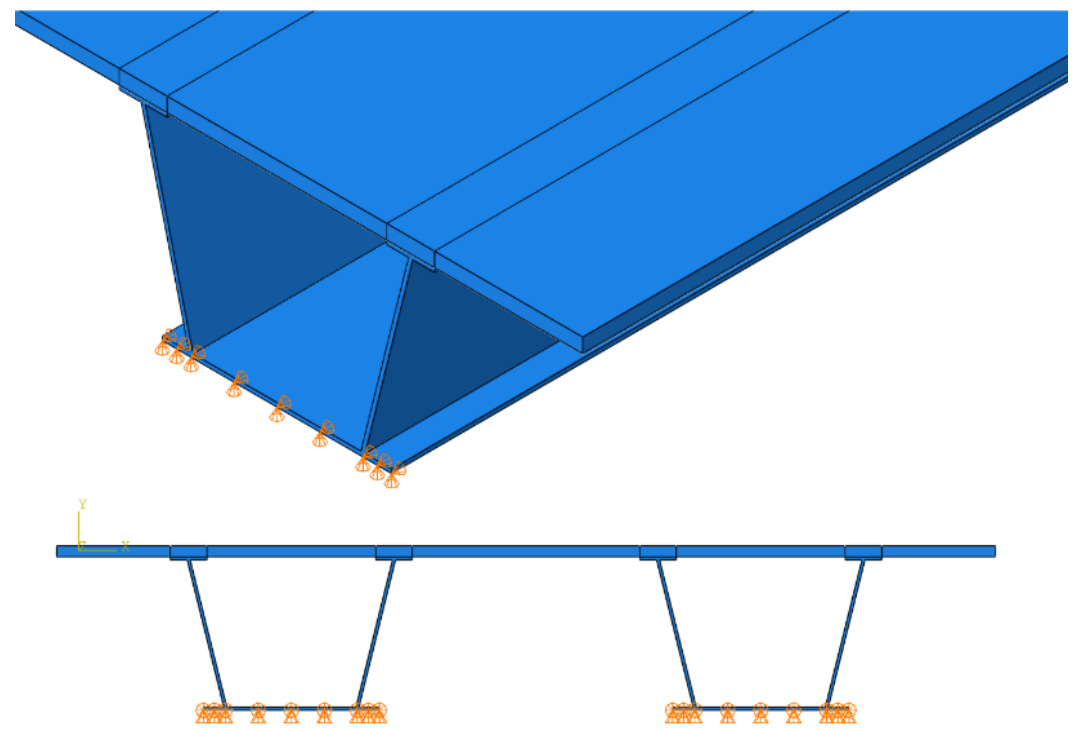

Figure 5. Boundary conditions of the models.

The loading, in turn, was defined for the composite section to reach the plastic behavior and applied with maximum loading steps of $2.5 \%$ of the total value, as a pressure distributed over the entire upper surface of the board. Figure 6 shows the loading and restriction of a model in the double box configuration.

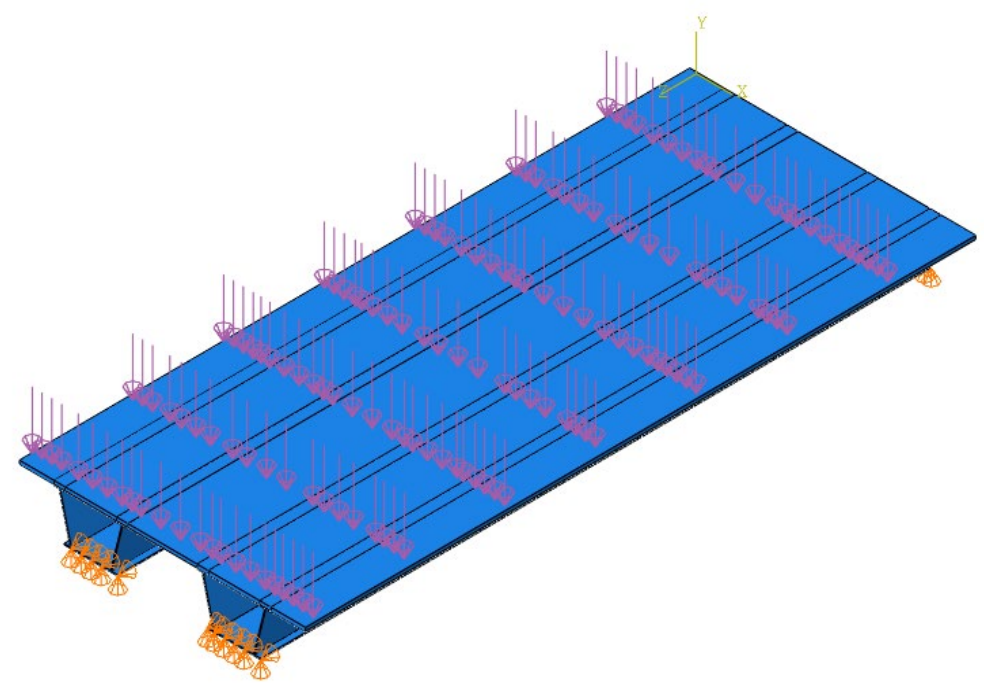

Figure 6. Application of loading models.

As for the mechanical properties of steel and concrete materials, both were satisfactorily described by a constitutive stress-strain relationship with perfect elastoplastic behavior. For steel, the Kirchhof model [24] was adopted, in which the yield strength of steel $\left(f_{y}\right)$ is $229.8 \mathrm{MPa}$. As for the longitudinal elastic modulus $(E)$ and the Poisson's ratio in elastic regime $(v)$, the values of $200 \mathrm{GPa}$ and 0.3 were used, respectively. In turn, the compressive cylinder strength $\left(f_{c k}\right)$ of $30 \mathrm{MPa}$ was adopted for concrete, culminating in an elasticity module of 30,672.46 MPa. The value of the Poisson's ratio in elastic regime of the admitted concrete was 0.2. Table 2 presents the properties of the materials. As the neutral plastic axis of all models are located in the steel box girder, the concrete was modeled considering only your compression behavior. Figure 7 shows a stress-strain curves used for steel and concrete, respectively. 
Table 2. Materials mechanical properties for parametric study.

\begin{tabular}{cccc}
\hline MATERIAL & E [MPa] & v & YIELD STRENGTH [MPa] \\
\hline Steel & 200,000 & 0.3 & 229.8 \\
\hline Concrete & $30,672.46$ & 0.2 & 30.0 \\
\hline
\end{tabular}

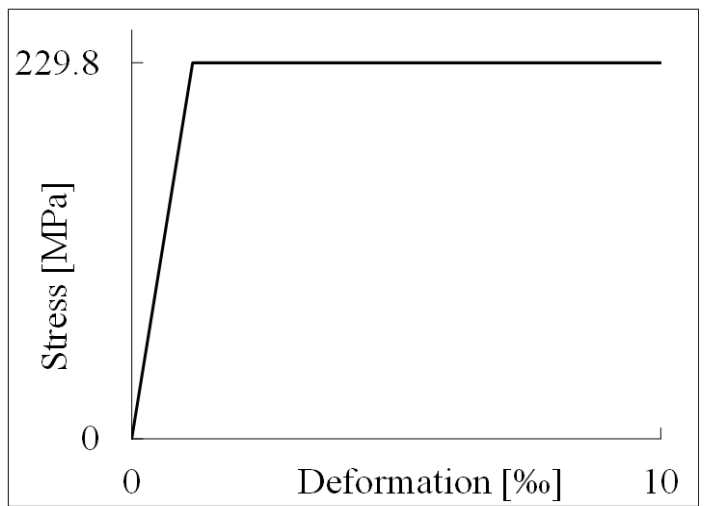

(a)

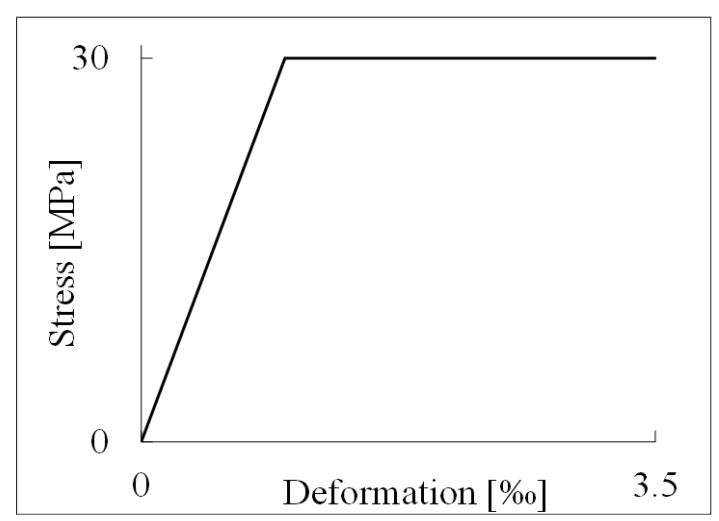

(b)

Figure 7. Stress-strain curve of steel (a) and concrete (b). Adapted from Kirchhof [24].

The most suitable mesh to discretize the model was defined after analyzing the influence of its level of refinement on the results, culminating in a mesh of $10 \mathrm{~cm}$ in the $\mathrm{x}$ direction, $10 \mathrm{~cm}$ in the $\mathrm{y}$ direction and $50 \mathrm{~cm}$ in the $\mathrm{z}$ direction, which presents coherent results for adequate processing time. Figure 8 shows a detail of the models' mesh.

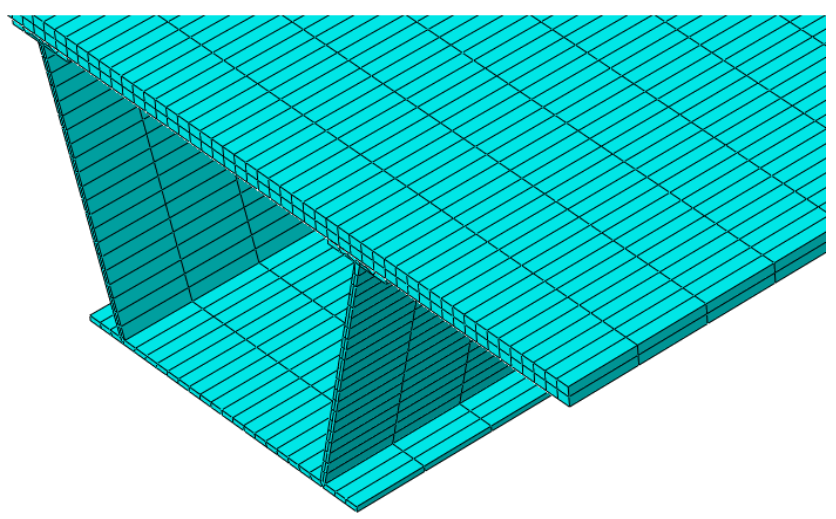

Figure 8. Detail of the typical mesh of the models.

In addition, to reduce processing time, the models were made with a condition of transversal and longitudinal symmetry.

\section{RESULTS AND DISCUSSIONS}

The results were divided for the simple box configuration and double box configuration.

The analysis of normal stresses was performed in the middle of the span and at the interface between the steel box girder and the concrete slab. A Specifically, the stress collection was carried out in the loading step of the start of the plastic behavior of the concrete of the slab because the effective width cannot be measured when such element is plasticized, as this would cause a uniform stress distribution and it would not be possible to analyze the effect of shear lag. Thus, the collection of stresses was made in the loading step where the first finite element of the slab was plasticized, that is, in the imminence of plasticization to start on the concrete slab. 
To determine the effective numeric width, the following steps were followed:

1. Measurement of the normal stresses on the half slab height, in the middle of the span;

2. Creation of the stress distribution curve along the cross section;

3. Calculation of the area under the curve using the finite sum method, in which 1000 points were used;

4. Calculation of the effective width using Equation (01), which was approximated to Equation (02), using this method. Figure 9 illustrates the variables in Equation (02).

$b_{e f}=\frac{\text { Area under the curve }}{\sigma_{\max }}(02)$

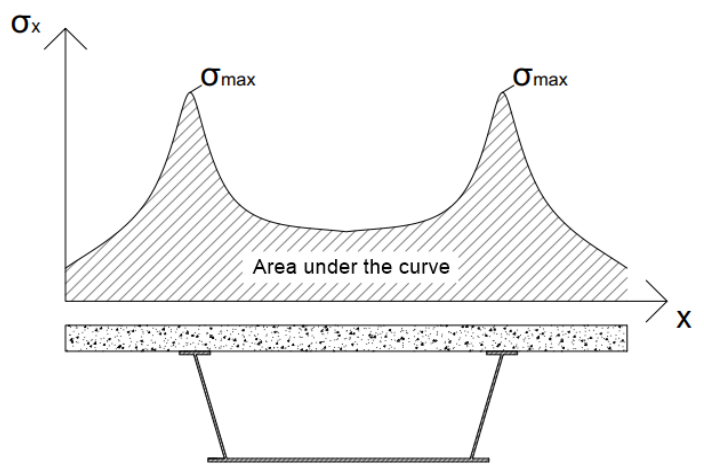

Figure 9. Variables for calculating the effective numeric width.

For all models, the stress distribution curve has the same typical configuration (with maximum stresses in the region of the beam webs). This demonstrates coherence with the curves found in the literature, in which the highest stress values are in the web region, showing the slab's contribution to the strength of the composite section. Figure 10 shows the normal stress distribution found in the models of simple and double box configuration, respectively.
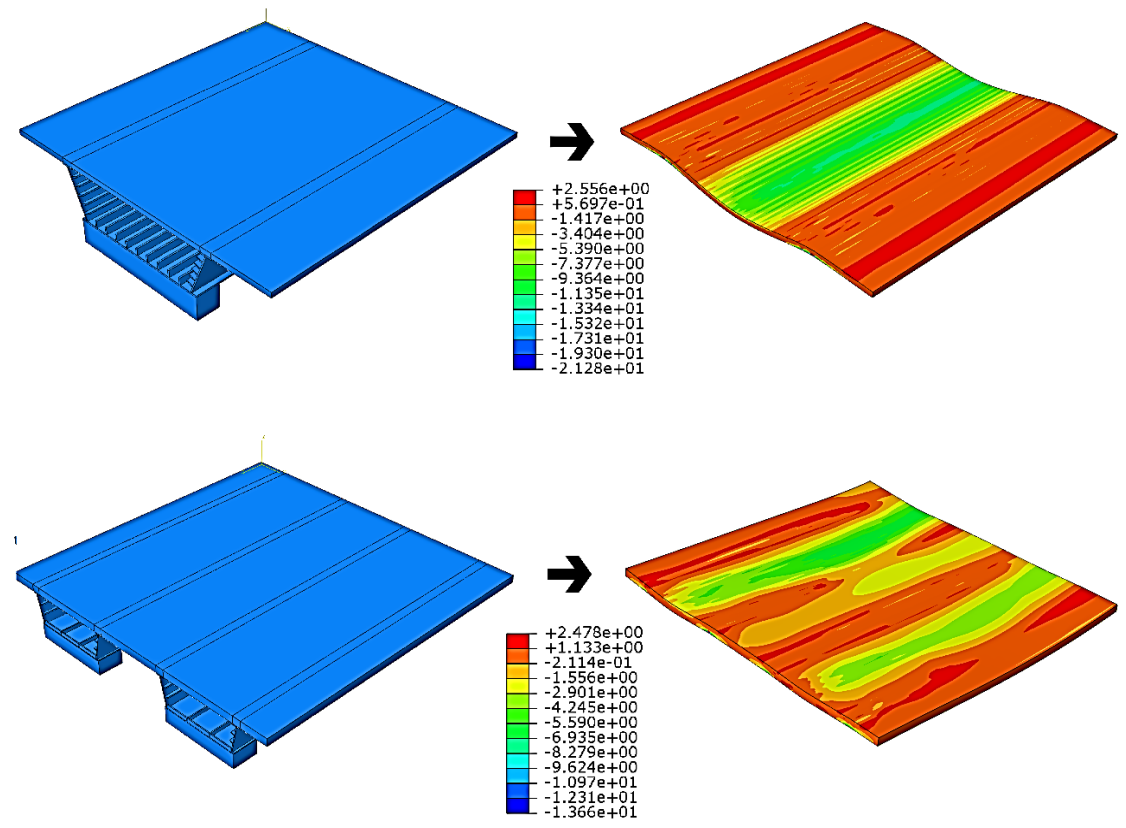

Figure 10. Stress distribution typical of models in single and double box configurations. [N/mm²]. 
It is worth noting that the maximum normal stresses occur where the concrete slab rests on the steel girder due to the greater rigidity of that location in the composite section and, as a consequence, there is the shear lag effect. Figures 11 and 12 illustrate, respectively, the occurrence of maximum stresses at the support points and the typical shape of the stress distribution curve for simple and double box girder configurations.

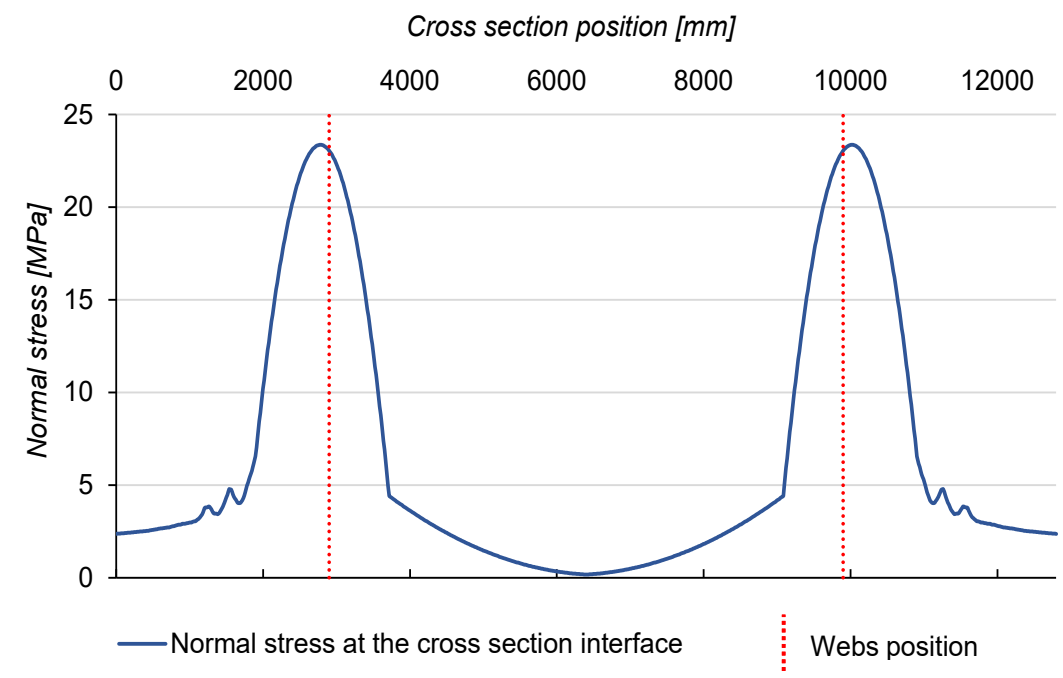

Figure 11. Occurrence of maximum normal stresses in the region of the webs in models with simple box configuration.

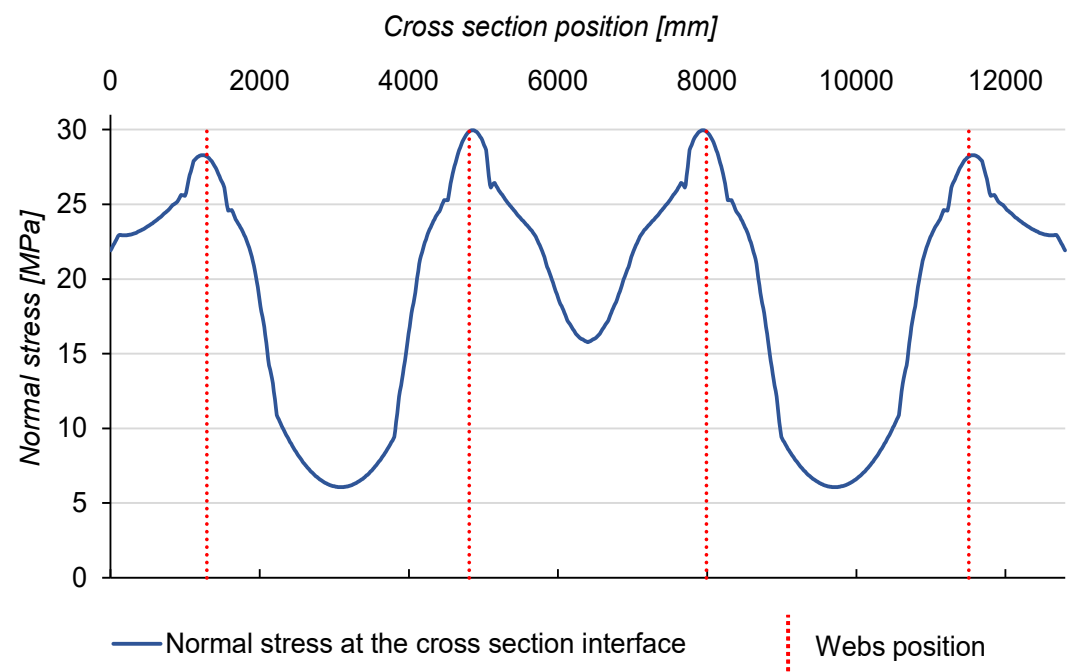

Figure 12. Occurrence of maximum normal stresses in the region of the webs in models with double box configuration.

\section{Simple box section}

\section{Influence of slab height}

In order to analyze the influence of the slab height in the calculation of the effective width, for a span of $3,000 \mathrm{~cm}$ and distance between webs of $620.0 \mathrm{~cm}$, eight numerical models with slab heights of $15.0 \mathrm{~cm} ; 20.0 \mathrm{~cm} ; 22.5 \mathrm{~cm} ; 25.0 \mathrm{~cm} ; 27.5 \mathrm{~cm} ; 30.0 \mathrm{~cm}$; $35.0 \mathrm{~cm}$; and $50.0 \mathrm{~cm}$, were analyzed. Table 3 summarizes the results obtained in calculating the effective width by varying the 
slab height. The results of Table 3 are expressed in the graph of Figure 13 in a comparison with the effective width calculated using the standards AASHTO [13], ABNT NBR 8800 [15] and EN 1994-2-2 [14].

Table 3. Numeric effective width versus slab height for single box configuration.

\begin{tabular}{ccc}
\hline MODEL & SLAB HEIGHT $\left(\boldsymbol{h}_{\boldsymbol{l}}\right)[\mathbf{c m}]$ & EFFECTIVE WIDTH $\left(\boldsymbol{b}_{\boldsymbol{e}} \boldsymbol{f}\right)[\mathbf{c m}]$ \\
\hline 1 & 15.0 & 201.2 \\
\hline 2 & 20.0 & 257.8 \\
\hline 3 & 22.5 & 270.7 \\
\hline 4 & 25.0 & 289.7 \\
\hline 5 & 27.5 & 309.3 \\
\hline 6 & 30.0 & 322.0 \\
\hline 7 & 35.0 & 325.2 \\
\hline 8 & 50.0 & 320.9 \\
\hline
\end{tabular}

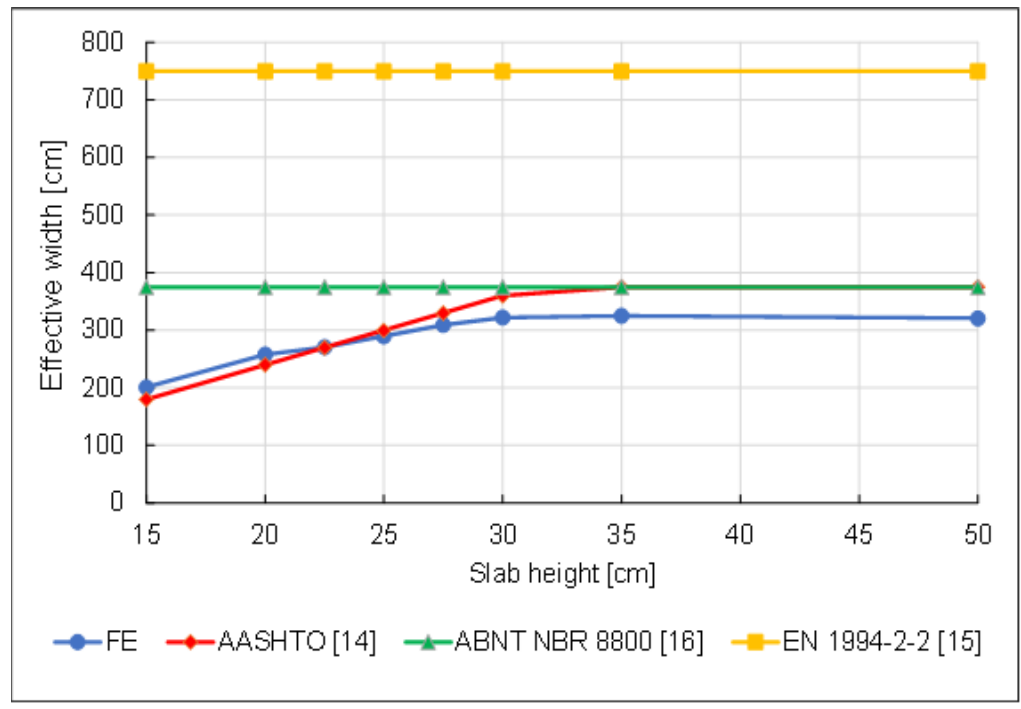

Figure 13. Effective width versus slab height for single box configuration.

It is possible to observe that the effective width curve as a function of the slab height has an increase that grows proportionally to the usual slab values, that is, up to a height of $30.0 \mathrm{~cm}$. Discarding models 7 and 8 - which have unusual slab heights - there is an average ratio between the effective width and the slab height of 11.98 , which is very close to that described by the AASHTO standard [13]. Such results can be seen in Table 4. Comparing the numerical effective width with that recommended by ABNT NBR 8800 [15] and EN 1994-2-2 [14], great divergences were observed, especially in relation to the European standard, which presented effective width values considerably higher than those found in numerical analyzes.

Table 4. Relationship between the effective numerical width and the slab height for simple box configuration.

\begin{tabular}{|c|c|c|c|}
\hline MODEL & SLAB HEIGHT $\left(h_{l}\right)[\mathrm{cm}]$ & EFFECTIVE WIDTH $\left(b_{e f}\right)[\mathrm{cm}]$ & $\frac{b_{e f}}{h_{l}}$ \\
\hline 1 & 15.0 & 201.2 & 13.42 \\
\hline 2 & 20.0 & 257.8 & 12.89 \\
\hline 3 & 22.5 & 270.7 & 12.03 \\
\hline 4 & 25.0 & 289.7 & 11.59 \\
\hline 5 & 27.5 & 309.3 & 11.25 \\
\hline 6 & 30.0 & 322.0 & 10.73 \\
\hline \multicolumn{3}{|c|}{ Average } & 11.98 \\
\hline
\end{tabular}




\section{Influence of span length}

In the study of the influence of span length, five numerical models were developed. For a slab height of $25.0 \mathrm{~cm}$ and a distance between webs of $620.0 \mathrm{~cm}$, the span length was modeled with: $1.000 .0 \mathrm{~cm} ; 2,000.0 \mathrm{~cm} ; 3,000.0 \mathrm{~cm}$; $4,000.0 \mathrm{~cm}$; and $5,000.0 \mathrm{~cm}$. Table 5 summarizes the results obtained in calculating the effective width for the five models described.

Table 5. Relationship between the effective numerical width and the longitudinal span length for the simple box configuration.

\begin{tabular}{cccc}
\hline MODEL & SPAN [cm] & EFFECTIVE WIDTH $\left(\boldsymbol{b}_{\text {ef }}\right)[\mathbf{c m}]$ & $\frac{S P A N}{\boldsymbol{b}_{\text {ef }}}$ \\
\hline 9 & 1000.0 & 259.9 & 3.85 \\
\hline 10 & 2000.0 & 275.5 & 7.26 \\
\hline 11 & 3000.0 & 289.7 & 10.36 \\
\hline 12 & 4000.0 & 288.8 & 13.85 \\
\hline 13 & 5000.0 & 286.5 & 17.45 \\
\hline
\end{tabular}

Observing the results, it is noted that the span length influences the effective width calculation up to $3,000 \mathrm{~cm}$. After this limit, the models showed a practically constant result for the effective width (possibly due to the effective width being governed by the height of the slab and not by the span anymore). This shows that higher span values do not have much influence on this calculation. This fact becomes even clearer when looking at the graph shown in Figure 14, which makes a comparison of the numerical effective width with that calculated by the AASHTO [13], ABNT NBR 8800 [15] and EN 1994-2-2 [14] standards.

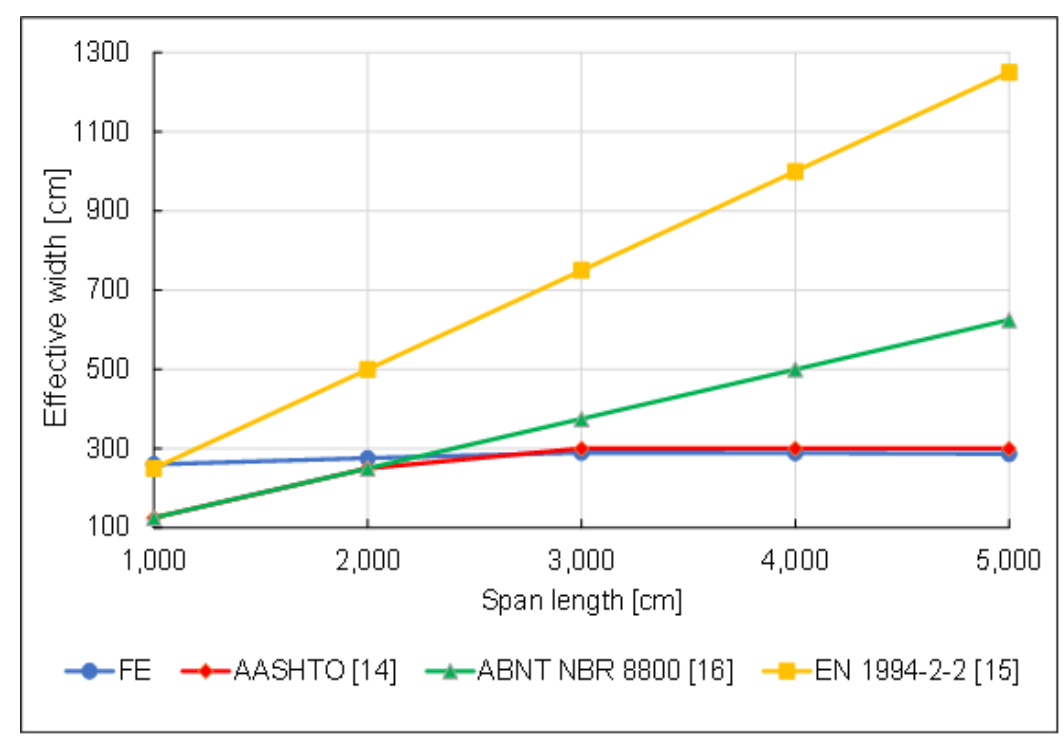

Figure 14. Effective width versus span length for single box configuration.

AASHTO's recommendations [13] approached the numerical effective width for spans greater than $3,000 \mathrm{~cm}$. Furthermore, the requirements of ABNT NBR 8800 [15] and EN 1994-2-2 [14] showed considerable divergences especially the European standard, which again provided values of effective width greater than those found.

\section{Transversal cantilever influence (distance between webs)}

In the analysis of the influence of the transversal cantilever distance, fixing the slab height at $20.0 \mathrm{~cm}$ and the span length at $5,000 \mathrm{~cm}$, the cantilever distances were: $350.0 \mathrm{~cm} ; 340.0 \mathrm{~cm} ; 330.0 \mathrm{~cm} ; 320.0 \mathrm{~cm} ; 310.0 \mathrm{~cm}$; and $300.0 \mathrm{~cm}$. Table 6 shows the results obtained. 
Table 6. Relationship between the effective numerical width and the distance between webs for the simple box configuration.

\begin{tabular}{ccccc}
\hline MODEL & $\begin{array}{c}\text { CANTILEVER } \\
{[\mathbf{c m}]}\end{array}$ & $\begin{array}{c}\text { DISTANCE AMONG WEBS }(\boldsymbol{w}) \\
{[\mathbf{c m}]}\end{array}$ & $\begin{array}{c}\text { EFFECTIVE WIDTH }\left(\boldsymbol{b}_{\boldsymbol{e f}}\right) \\
{[\mathbf{c m}]}\end{array}$ & $\begin{array}{c}\boldsymbol{b}_{e f} \\
\boldsymbol{w}\end{array}$ \\
\hline 14 & 350.0 & 580.0 & 216.3 & 0.37 \\
\hline 15 & 340.0 & 600.0 & 205.0 & 0.34 \\
\hline 16 & 330.0 & 620.0 & 192.4 & 0.31 \\
\hline 17 & 320.0 & 640.0 & 174.0 & 0.27 \\
\hline 18 & 310.0 & 660.0 & 130.9 & 0.20 \\
\hline 19 & 300.0 & 680.0 & 124.0 & 0.18 \\
\hline
\end{tabular}

Figure 15 shows the behavior of the effective width as a function of the distance between the girder webs and those calculated by the normalizations AASHTO [13], ABNT NBR 8800 [15] and EN 1994-2-2 [14]. The numerical analyzes provided results closer to the recommendations of AASHTO [13], while ABNT NBR 8800 [15] and EN 1994-2-2 [14] resulted in higher $b_{e f}$ values.

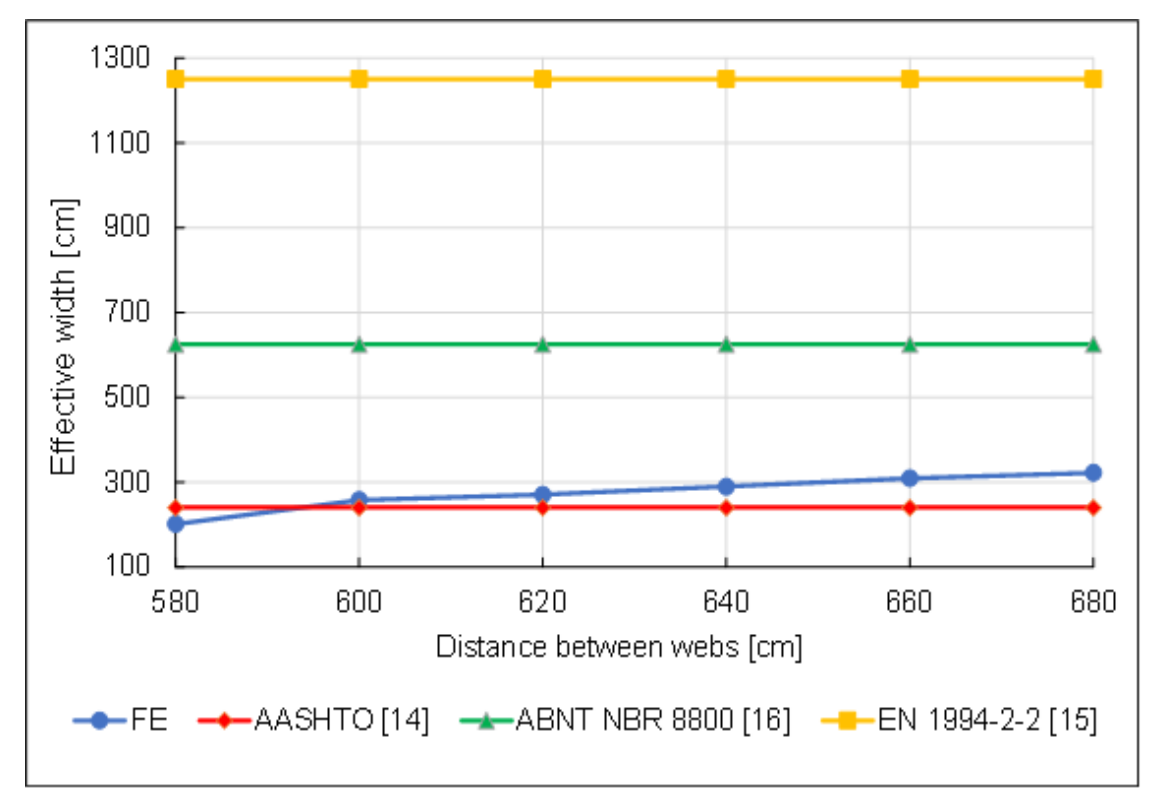

Figure 15. Effective width versus distance between webs for simple box configuration.

In addition, it is noted that the effective width decreases as the webs are separated. This phenomenon is explained by the fact that the rigidity of one web is not able to maintain the "absorption" of normal stresses until the other. It is also worth noting that the average quotient of the width between webs for the effective width is $0.28 \cong 1 / 4$.

\section{Comparison between the effective numerical width and that established by the standards}

In all parameterizations, a large discrepancy is noticed between the effective numerical width calculated numerically in Abaqus ${ }^{\circledR}$ [23] and those prescribed by ABNT NBR 8800 [15] and EN 1994-2-2 [14]. The reason for this is that such normalizations limit the effective width only by the length of the span and the distance between girders. As in the simple box configuration there is only one box girder, the effective width found is greater than that found numerically.

Overall, numerical results were closer to the recommendations of AASHTO [13], especially in the variation of slab height and span length. However, when the distance between webs was varied, AASHTO [13] provided values of effective width greater than those found numerically.

Finally, for the simple box configuration, it is noted that the standards have values of effective width higher (in most cases) than those calculated numerically - especially when compared with ABNT NBR 8800 [15] and EN 1994-2- 2 [14]. 


\section{Double box section}

\section{Influence of slab height}

For models in a double box section, the influence of the slab height on the effective width calculation was analyzed by simulating six numerical models with the following heights: $15.0 \mathrm{~cm} ; 20.0 \mathrm{~cm} ; 22.5 \mathrm{~cm} ; 25.0 \mathrm{~cm} ; 27.5 \mathrm{~cm}$ and $30.0 \mathrm{~cm}$. The span length was set at $3,000 \mathrm{~cm}$ and the distance between the center of steel box girders at $620,0 \mathrm{~cm}$. Table 7 shows the results obtained in the calculation of the effective width by varying the slab height and Figure 16 expresses these results graphically in a comparison with the effective width established by the codes AASHTO [13], ABNT NBR 8800 [15] and EN 1994 - 2-2 [14].

Table 7. Relationship between the effective numerical width and the slab height for the double box configuration.

\begin{tabular}{|c|c|c|c|}
\hline MODEL & SLAB HEIGHT $\left(h_{l}\right)[\mathrm{cm}]$ & EFFECTIVE WIDTH $\left(b_{e f}\right)[\mathrm{cm}]$ & $\frac{b_{e f}}{h_{l}}$ \\
\hline 20 & 15.0 & 210.7 & 14.05 \\
\hline 21 & 20.0 & 215.3 & 10.77 \\
\hline 22 & 22.5 & 217.4 & 9.66 \\
\hline 23 & 25.0 & 223.1 & 8.92 \\
\hline 24 & 27.5 & 224.5 & 8.16 \\
\hline 25 & 30.0 & 219.1 & 7.30 \\
\hline \multicolumn{3}{|c|}{ Average } & 9.81 \\
\hline
\end{tabular}

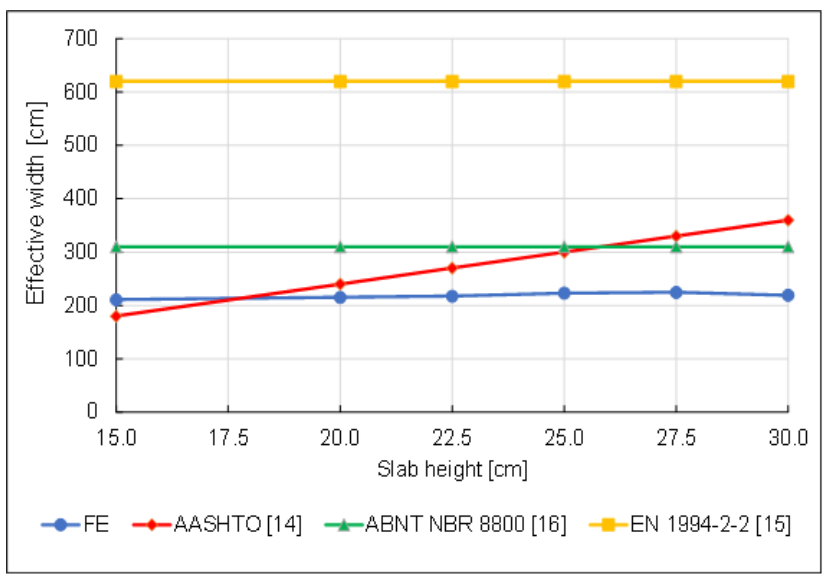

Figure 16. Effective width versus slab height for double box configuration.

Analyzing the stress distribution, it was found that as the slab height increased, the maximum stress in the central webs became smaller. This is explained by the fact that the plastic neutral axis goes up to the concrete slab as the height of the slab increases. Furthermore, the drop in the effective width value in the model with a slab height of $30.0 \mathrm{~cm}$ is explained by the slab's height no longer being the limiting factor of the shear lag effect. Finally, it appears that the average quotient of the effective width by the height of the slab is approximately 10 .

With the exception of the model with a $15.0 \mathrm{~cm}$ slab height, the recommendations of AASHTO [13], ABNT NBR 8800 [15] and EN 1994-2-2 [14] presented higher effective width values - especially EN 1994-2-2 [14].

\section{Influence of span length}

In the analysis of the influence of the span length for the calculation of the effective width in a double box section, five numerical models were simulated. For a slab height of $25.0 \mathrm{~cm}$, distance from center to center of box girders of $620.0 \mathrm{~cm}$, the span length was designed with: $1.000 .0 \mathrm{~cm} ; 2,000.0 \mathrm{~cm} ; 3,000.0 \mathrm{~cm} ; 4,000.0 \mathrm{~cm}$; and $5000.0 \mathrm{~cm}$. Table 8 presents the results obtained. Figure 17 presents these results graphically compared to the effective width of the AASHTO [13], ABNT NBR 8800 [15] and EN 1994-2-2 [14] standards. 
Table 8. Relationship between the effective numerical width and the longitudinal span length for the double box configuration.

\begin{tabular}{cccc}
\hline MODEL & SPAN [cm] & EFFECTIVE WIDTH $\left(\boldsymbol{b}_{\boldsymbol{e} f}\right)[\mathbf{c m}]$ & $\frac{S P A N}{\boldsymbol{b}_{\text {ef }}}$ \\
\hline 26 & $1,000.0$ & 248.4 & 4.03 \\
\hline 27 & $2,000.0$ & 275.5 & 7.26 \\
\hline 28 & $3,000.0$ & 277.1 & 10.83 \\
\hline 29 & $4,000.0$ & 277.9 & 14.39 \\
\hline 30 & $5,000.0$ & 279.2 & 17.91 \\
\hline
\end{tabular}

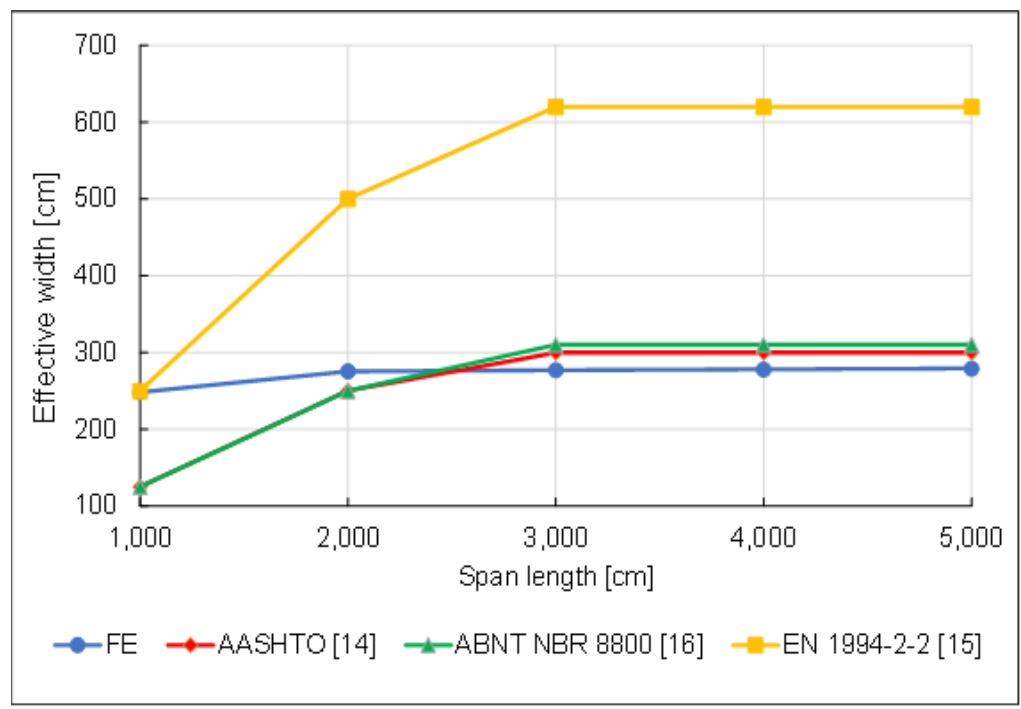

Figure 17. Effective width versus span length for double box configuration.

With the exception of the model with a span of $1,000 \mathrm{~cm}$, the effective numerical width remained practically constant. Similar to the simulations for simple box configuration, it is explained that the effective width was being limited by the height of the slab and no longer by the span.

The $b_{e f}$ values recommended by EN 1994-2-2 [14] were considerably higher than all numerical results. As for the recommendations of AASHTO [13] and ABNT NBR 8800 [15], with the exception of the model with a span length of $1,000 \mathrm{~cm}$, the results showed greater agreement.

\section{Transversal cantilever influence (distance between girders)}

In assessing the influence of the effective width against the variation in the distance between box girders $(a)$, fixing the slab height at $22.5 \mathrm{~cm}$ and the span length at $3,000 \mathrm{~cm}$, five models were simulated for the following distance values between girders: $580.0 \mathrm{~cm} ; 600.0 \mathrm{~cm} ; 620.0 \mathrm{~cm} ; 640.0 \mathrm{~cm}$; and $660.0 \mathrm{~cm}$. Table 9 shows the results obtained.

Table 9. Relationship between the effective numerical width and the distance between girders for the double box configuration.

MODEL

\begin{tabular}{ll}
\hline 31 \\
32 \\
33 \\
34 \\
35
\end{tabular}

EFFECTIVE WIDTH $\left(b_{e f}\right)[\mathrm{cm}]$

\begin{tabular}{|c|c|c|}
\hline 580.0 & 255.7 & 0.44 \\
\hline 600.0 & 249.4 & 0.42 \\
\hline 620.0 & 235.2 & 0.38 \\
\hline 640.0 & 217.4 & 0.34 \\
\hline 660.0 & 213.3 & 0.32 \\
\hline Average & & 0.38 \\
\hline
\end{tabular}


Figure 18 represents the numerical effective width distribution for such models and compares the results with the effective widths calculated by AASHTO [13], ABNT NBR 8800 [15] and EN 1994-2-2 [14]. The effective numerical width was smaller than that recommended by all methods, with emphasis on EN 1994-2-2 [14], which presented much higher values.

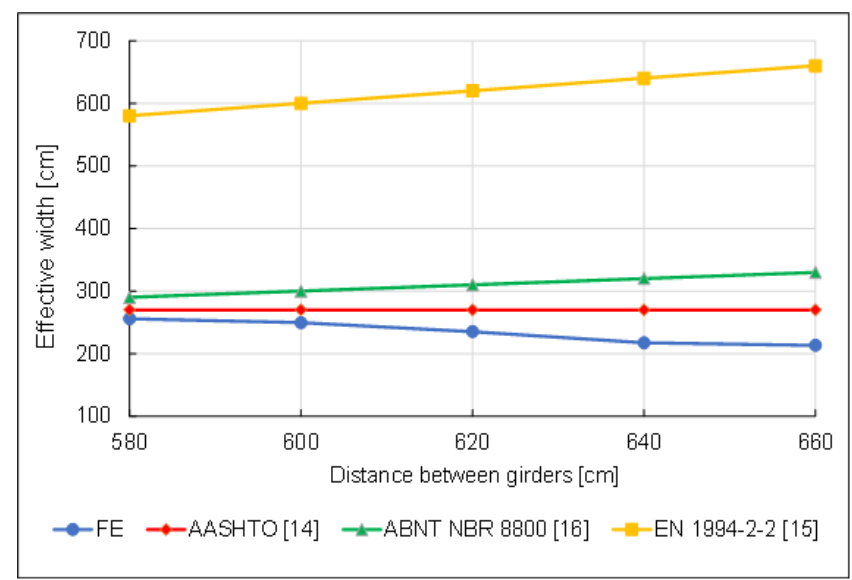

Figure 18. Effective width versus distance between girders for double box configuration.

It is also noted that the effective width has its value reduced as the box girders are moved away. This variation is explained by the girders contributed together to maintain high tensions in the region between them. Analyzing an average relationship between the effective width and the distance between the girders, it is recommended that the effective width is not less than $30 \%$ of the distance from the center to the center of box girders.

Finally, it is worth mentioning that for the analysis of the influence of the span length and the influence of the transversal cantilever distance in double box configuration, a mesh refinement twice higher than that used in the others was necessary. This is attributed to the difference in the value of the effective numerical width between models 23 and 28 and 22 and 23, which have the same geometry.

\section{Comparison between the effective numerical width and that established by the standards}

Comparing the curves of the effective numerical width with those prescribed by the standards for the double box configuration, there is a great disparity in relation to that established by EN 1994-2-2 [14].

In addition, the effective numerical width and those calculated by AASHTO [13] and ABNT NBR 8800 [15] showed similar values. The reason for this is that the Brazilian standard limits the effective width to half the distance between center to center between adjacent girders - different from EN 1994-2-2 [14], which limits the effective width in relation to the span and the average of the center distance between the girder analyzed and the adjacent girders.

In general, the technical standards have values of effective width higher (in most cases) than those calculated numerically - especially EN 1994-2-2 [14].

\section{Suggestion of formulation}

Based on the results presented, for steel-concrete composite box girder bridges in simple box configuration, it is recommended that the effective width of the slab must not exceed: (for each web):

- One-fourth of the span length of the girder;

- Half the distance from center to center of girders;

- 12 times the least thickness of the slab.

In turn, for steel-concrete composite bridges in double box configuration, it is recommended that the effective width of the slab must not exceed: (for each box girder): 
- One-fourth of the span length of the girder;

- $30 \%$ of the distance from center to center of girders;

- 10 times the least thickness of the slab.

\section{CONCLUSIONS}

A numerical analysis was developed to determine the effective width in steel-concrete composite box girder bridges with simple and double box section. For this purpose, the influence of the span, the height of the slab and the distance between webs (simple box configuration) and girders (double box configuration) were evaluated. The numerical values of effective width were compared with those obtained by the AASHTO [13], ABNT NBR 8800 [15] and EN 1994-2-2 [14] standards for beams with I-profiles.

Among the analyzed parameters, the height of the slab was the one that most influenced the calculation of the effective width, showing a proportional increase with the increase in the height of the slab in the range from $15.0 \mathrm{~cm}$ to $30.0 \mathrm{~cm}$.

The span length, in turn, influenced the effective width value for spans up to $3,000 \mathrm{~cm}$. For larger spans, the effective width has not been significantly changed, due to the fact that the effective width is being limited by the height of the concrete slab and no longer by the span.

Finally, it is noted that the effective width decreases as the webs and girders are separated. This phenomenon is explained by the rigidity of a single web not being able to maintain the "absorption" of normal stresses in the section until the other.

In general, AASHTO [13] was the technical standard that most converged with the results found numerically. The recommendations of ABNT NBR 8800 [15] and, mainly, of the European standard EN 1994-2-2 [14], presented values of effective width higher than those of numerical analysis.

More specifically about AASHTO [13], which resulted in the best concordances, comparing the effective width values obtained numerically with those recommended by the American standard, it is clear that the relationship $b_{e f} \leq \frac{\operatorname{Span}}{4}$ is confirmed. However, the limitation of 12 times the thickness of the slab for the double box configuration and the limitation of the effective width as being less than or equal to the distance between girders or webs, overestimates the contribution of the slab to the strength of the composite section.

Therefore, based on the numerical results discussed above, it is concluded that the recommendations prescribed by the AASHTO [13], ABNT NBR 8800 [15] and EN 1994-2-2 [14] standards for steel-concrete composite bridges with I-girders, should not be applied directly to box girder sections. Thus, for the calculation of the effective width of steelconcrete composite box girder bridges, it is recommended to use the formulation presented in item 4.3 of this work. It is also worth noting the need for additional numerical and experimental studies to prove and rectify the formulation.

\section{ACKNOWLEDGMENTS}

The authors would like to thank CNPq, process 120583/2017-8 and the entire team of IBRACON Structures and Materials Journal for the opportunity to publicize the work.

\section{REFERENCES}

[1] G. S. Veríssimo, "Desenvolvimento de um conector de cisalhamento em chapa dentada para estruturas mistas de aço e concreto e estudo do seu comportamento,” M.S. thesis, Univ. Fed. Minas Gerais, Belo Horizonte, 2007.

[2] S. de Nardin and A. S. C. Souza, "Sistemas de vigas mistas contínuas e semicontínuas para edifícios," in An. XXXIII Jorn. Sudam. Ing. Estructural, Santiago, Chile, 2008, pp. 1-10.

[3] I. T. Kotinda, "Modelagem numérica de vigas mistas aço-concreto simplesmente apoiadas: ênfase ao estudo da interface laje-viga," M.S. thesis, Esc. Eng. São Carlos, Univ. São Paulo, São Carlos, 2006.

[4] A. S. C. Souza, W. F. Maia, and S. de Nardin, "Análise numérica de vigas mistas de aço e concreto protendidas," Rev. Estrutura Aco, vol. 4, pp. 1-15-1, 2015.

[5] F. Pinho and I. H. Bellei, Pontes e Viadutos em Vigas Mistas, 1. ed. Rio de Janeiro: IBS/CBCA, 2007.

[6] D. Orlando, Z. M. C. Pravia, and G. A. Drehmer “Análise de pontes mistas de aço e concreto pelo método dos elementos finitos," in An. XVII Cong. Reg. Iniciac. Cient. Tec., Porto Alegre, 2003.

[7] V. J. L. Souza, "Contribuição ao projeto e dimensionamento da superestrutura de pontes rodoviárias em vigas mistas de aço e concreto,” M.S. thesis, Dep. Eng. Civ., Univ. Fed. São Carlos, São Carlos, 2006. 
[8] H. P. Faria and Z. M. C. Pravia, "Metodologia de cálculo de uma ponte em caixão metálico com laje em concreto," in An. VII Cong. Bras. Pontes e Estrut., Rio de Janeiro, 2014.

[9] J. Brozzetti, "Design development of steel-concrete composite bridges in France," J. Construct. Steel Res., vol. 55, no. 1-3, pp. 229243, 2000.

[10] S. Nakamura, Y. Momiyama, T. Hosaka, and K. Homma, "New technologies of steel/concrete composite bridges," J. Construct. Steel Res., vol. 58, no. 1, pp. 99-130, 2002.

[11] D. C. Iles, Design Guide for Composite Box Girder Bridges, 2th ed. Ascot, England: SCI, 1994.

[12] B. Chavel and J. Rivera, Steel Bridge Design Handbook Design - Example 5 - Three-Span Continuous Horizontally Curved Composite Steel Tub-Girder Bridge, 1th ed. USA: FHWA, 2015.

[13] American Association of State Highway and Transportation Officials, LRFD Bridge Design, 2017.

[14] European Committee for Standardization, Eurocode 4 - Design of Composite Steel and Concrete Structures - Part 2: General Rules and Rules for Bridges, EN 1994-2-2, Brussels, Belgium, 2005.

[15] Associação Brasileira de Normas Técnicas, Design of Steel and Composite Structures for Buildings, NBR 8800, 2008.

[16] L. G. Reginato, "Estudo da largura efetiva de vigas mistas de aço-concreto em carregamento de serviço: método dos elementos finitos versus códigos de projeto,” M.S. thesis, Dep. Eng. Civ., Univ. Fed. Rio Grande do Sul, Porto Alegre, 2017.

[17] P. Patel, "LRFD design of double composite box girder bridges," M.S. thesis, Univ. South Florida, Florida, USA, 2009.

[18] C. Amadio and M. Fragiacomo, "Effective width evaluation for steel-concrete composite beams," J. Construct. Steel Res., vol. 58, no. 3, pp. 373-388, 2002.

[19] T. Salama and H. H. Nassif, "Effective flange width for composite steel beams," J. Eng. Res., vol. 8, no. 1, pp. $28-43,2011$.

[20] M. Abbu, T. Ekmekyapar, and M. F. E. Ozakça, “Analysis of stresses in composite box girder bridges,” in Proc. Int. Civ. Eng. Architecture Symposium for Academicians, Antalaya, Turkey, 2014.

[21] L. Zhu, J. G. Nie, F.-X. Li, and W.-Y. Ji, "Simplified analysis method accounting for shear-lag effect of steel-concrete composite decks," J. Construct. Steel Res., vol. 115, pp. 62-80, 2015.

[22] H. Yuan, H. Deng, Y. Yang, Y. Weijian, and Z. Zhenggeng, "Element-based effective width for deflection calculation of steelconcrete composite beams," J. Construct. Steel Res., vol. 121, pp. 163-172, 2016.

[23] Abaqus ${ }^{\circledR}$. Dassault Sistèmes Simulia. Abaqus 6.18. 2016.

[24] L. D. Kirchhof, "Uma contribuição ao estudo de vigas mistas aço-concreto simplesmente apoiadas em temperatura ambiente e em situação de incêndio,” M.S. thesis, Esc. Eng. São Carlos, Univ. São Paulo, São Carlos, 2004.

Author contributions: RSN: conceptualization, methodology, numerical analysis, writing; ASCS: formal analysis, methodology, supervision, review.

Editors: Leandro Mouta Trautwein, José Luiz Antunes de Oliveira e Sousa, Guilherme Aris Parsekian. 